Article

\title{
Khyentse Norbu's Film Travelers and Magicians: Experiencing Impermanence, No Self, and Emptiness
}

\section{Catherine Benton}

Asian Studies and Religion Department, Lake Forest College, Lake Forest, IL 60045, USA; benton@lakeforest.edu

Received: 13 March 2018; Accepted: 3 April 2018; Published: 11 April 2018

check for updates

\begin{abstract}
This article examines the filmmaking of writer and director Khyentse Norbu (Dzongsar Jamyang Khyentse Rinpoche), a Tibetan-Bhutanese lama with major responsibilities as a senior Vajrayana teacher, and recognized as the third incarnation of the founder of the non-sectarian Khyentse lineage. Focusing particularly on his film Travelers and Magicians (2003), the article explores how Khyentse Norbu creates an experience of Buddhist seeing: an experience of impermanence [anitya], no self [anātma], dependent arising [pratītyasamutpāda], and emptiness [śūnyatā]. The filmmaker draws the audience into worlds that appear to exist and not exist, shaped as they are by these interrelated Buddhist realities. Moving back and forth between a frame story and its embedded narratives, the film invites the viewer to experience the emotional turmoil of two protagonists as emotions shape and re-shape their behavior and influence the actions of those around them. Identifying with the protagonists in Travelers and Magicians, the audience experiences the Buddhist perception that life is a myriad of mutually dependent realities: the powerful reality of illusion and the illusory nature of reality.
\end{abstract}

Keywords: causes and conditions; dependent arising [pratītyasamutpāda]; Dzongsar Jamyang Khyentse Rinpoche; emptiness; Guru Rinpoche; illusion; impermanence; liminal; no self; Padmasambhava; ritual; transformation

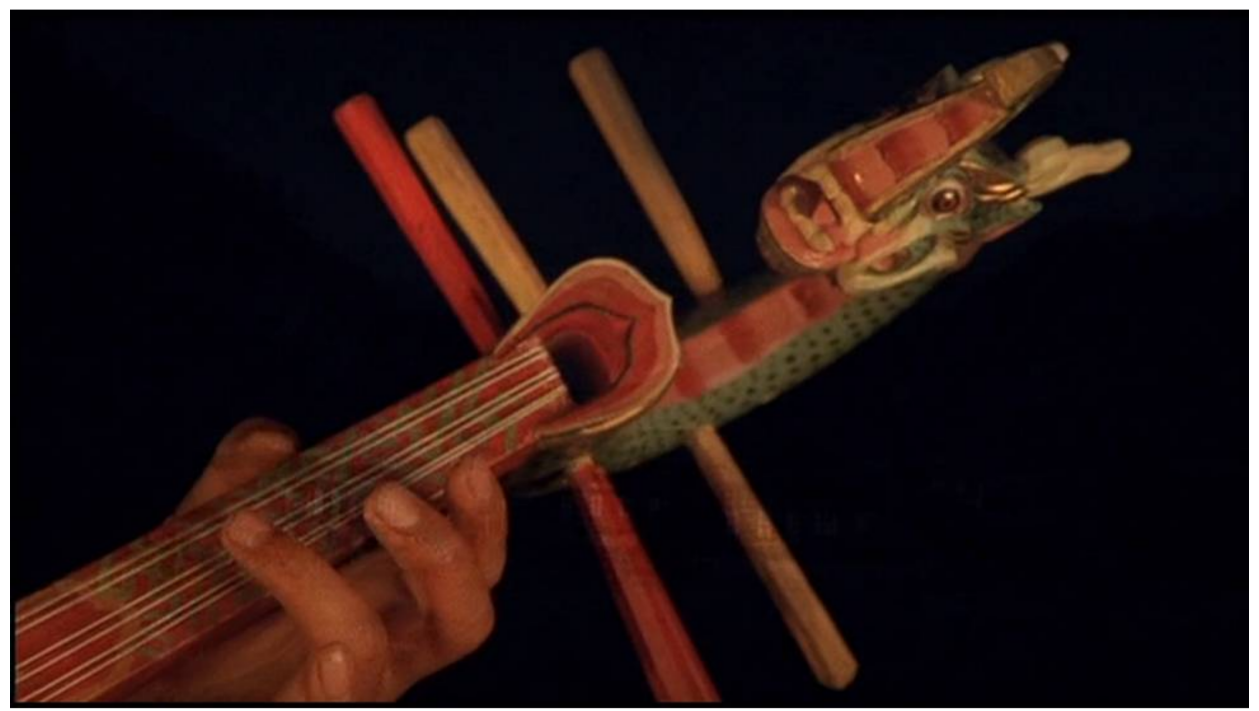

The drangyen, a lute-type Bhutanese stringed instrument, is played by the monk in the film as accompaniment to his storytelling. The drangyen, carved with a sea monster scaring away the evil spirits attracted to its beautiful music, is understood to have been brought to Bhutan by Guru Rinpoche in the 8th century. [from Travelers and Magicians]. 
Khyentse Norbu's Travelers and Magicians recounts the story of two young men: Dondup, a university graduate hoping to go to America, and Tashi, a farmer's son attending magician school. Both live in small, rural villages and both are unhappy with their lives. Lost in visions of more exciting futures, each young man winds up also lost in the present, wanting to leave his current circumstances. A story within a story within a story, the nested narrative structure of the film takes Dondup, and the audience, into Tashi's world and offers a kind of two-way mirror for us to see ourselves along with the two men. What is it about human beings that so quickly acts on emotion? What is desire? What is illusion? What is real?

The story of Dondup, a traveler leaving rural Bhutan for a more fulfilling life in America, provides the outer frame for the film's narrative. As Dondup begins his journey, others join him: a man selling apples, a father with his nineteen-year-old daughter, and a monk who tells the story of a young man called Tashi who is also seeking happiness outside his village. A reluctant student, Tashi has nevertheless been sent to school to learn the esoteric, magic skills of manipulating reality. Though he attends the class, his mind is filled with dreams of falling in love with a beautiful woman. One day, Tashi's mischievous younger brother, secretly studying magic himself, mixes an herbal mixture for Tashi which sends him stumbling into romantic love with painful complications. As Tashi becomes ever more tangled in his new life, Dondup in the parallel story begins to question his certainty that the grass is truly greener in America.

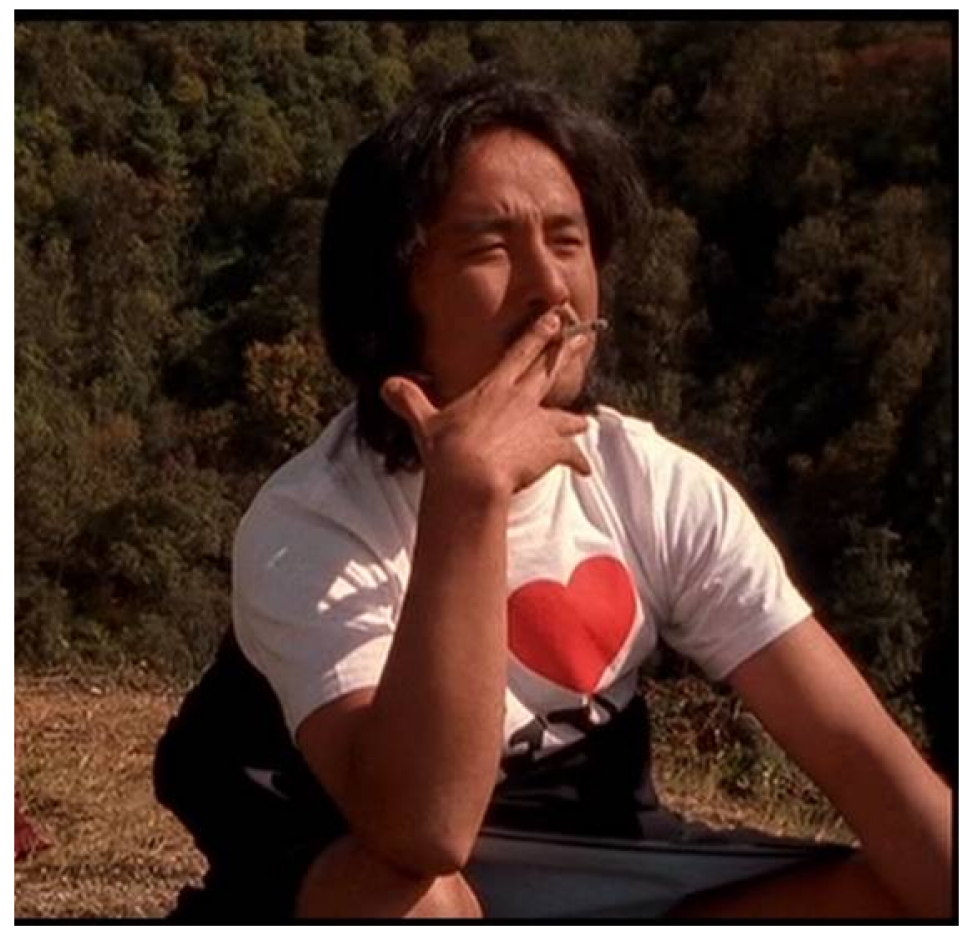

Dondup [from Travelers and Magicians].

While Tashi's narative is offered in the context of a magical dream, the events in Dondup's life are ostensibly "real". Yet the single-minded dreams and set perspectives of the two young men clearly run parallel. As Tashi's passions lead him to make one bad decision after another, Dondup wants to find out whether his alter ego will escape the painful consequences of his choices. Like Dondup, we as viewers hope for a happy ending, however unlikely. And like Tashi, we want to believe that suffering may not be inevitable, that desire can lead to happiness. 


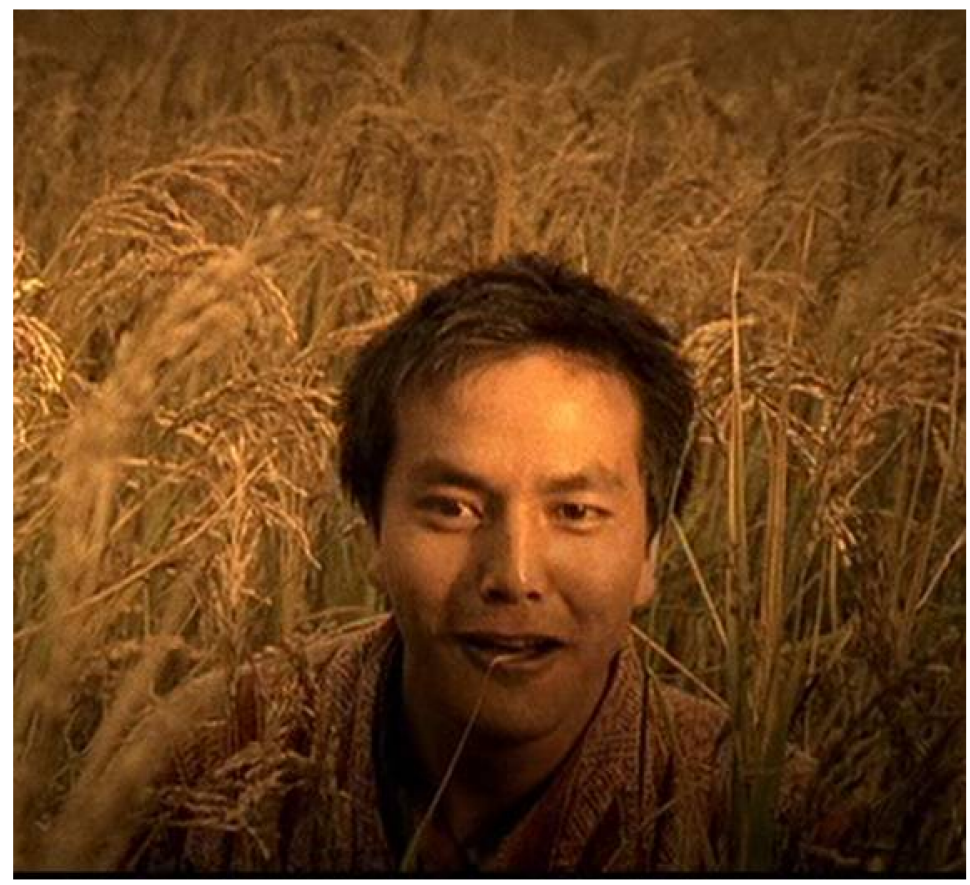

Tashi [from Travelers and Magicians].

Viewers of Travelers and Magicians meet the two principal characters at liminal junctures in their lives. Dondup is leaving his identity as a village government official and journeying to an imagined new life in America, and Tashi is riding into a mysterious forest. Straddling past and future, Dondup has become simply a traveler. He has no other identity defined by job, community, or family, though we know his suitcase contains one hastily packed photograph. Tashi, enjoying a mid-day break, moves into an even more pronounced liminal status when he unknowingly sips a drink containing magical herbs that propel him into another reality. The camera visually captures this liminal state by zooming out to film Tashi in an open field between school and farm, between dreams and duties, mounting a horse that is not a horse though it is galloping away with him. Neither here nor there, the animal literally transports Tashi to a space and time in-between.

Moving in and out of each young man's world, the film also creates a liminal reality for the viewer. While identifying with Tashi and the intensity of his feelings, we blink and begin commiserating with Dondup's determination to find a better life. Empathizing with them as they yearn for happiness, we find ourselves also desiring. In our role as the all-seeing audience, we desperately want each man to open his eyes wider, to see what is really there, beyond fantasies and desires. As we experience the worlds created by Tashi's and Dondup's thoughts and decisions, we want to say 'no': the roads you are following lead to suffering, not happiness. We empathize with the perspectives that lead to their decisions, but sit in the wings wanting them to see other options.

We root for Dondup and Tashi to let go of seeing themselves as fixed "selves". Rather, we want them to see their "selves" from a more Buddhist perspective, as constantly transitioning from one moment to the next, ever becoming someone new. As boyish Tashi becomes an adult transformed by guilt and grief, and Dondup begins to let go of his illusory future for a few moments, we begin to shift our thinking too. Immersed in their metamorphoses, we try out new ways of seeing our "selves".

Travelers and Magicians pointedly locates the abstract Buddhist teachings of no self and impermanence in the lives of Tashi and Dondup. Throughout the film, we experience the liminal realities of fluid selves, neither where they were nor where they may be going. Analogous to participating in a religious ritual that leads to a new identity and new relationship to the world-like marriage, bar/bat mitzvah, monastic vows as monks or nuns-Tashi and Dondup transition into new 
ways of seeing as they move through liminal experiences to new identities. During the time that we as viewers become Dondup and Tashi, we too allow our absolutes to be shaken loose.

The film mirrors a ritual structure that invites the individual into a liminal time and space from which one will emerge transformed. Like those setting out for a holy site who shed everyday identities to become pilgrims, Tashi and Dondup give up their previous identities to enter unknown worlds. Like pilgrims walking the Camino de Santiago de Compostela or making the journey to Mecca, the two men inhabit liminal space/time/identity, physically in-between where and who they were and who they will become. Their journeys visibly mark transitional time and space and lead inevitably to transformation and new identities.

Following the young men into this liminal state, the audience becomes immersed in Tashi's life which the film embeds within Dondup's life. Absorbing the mental states of the characters, the viewer's own perceptions refocus to see Tashi's story reflecting something of Dondup's mental state, and both characters reflecting the viewer's experiences of dreaming a hope into existence and losing it. Immersed in both narratives, the viewer becomes another traveler making these journeys, caught up in the enchantment of desire, doubting, and walking toward a transformation in which internal conflicts can be resolved. As Dondup hears about Tashi's desire for a beautiful Bhutanese woman, Dondup himself begins to notice the beauty of the young woman returning to the village he has abandoned. As Tashi becomes overwhelmed by feelings for a woman beyond his reach, Dondup begins to respond to the female energy of the young woman next to him. Sharing their liminal state, the viewer also experiences these emotions, along with the discomfort and questions they evoke.

As particular religious rituals make clear, the liminal state can engender new perspectives that emerge out of asking existential questions, facing new stages in life, or managing loss. Creating a liminal space/time, the ritual offers support for turning within to examine one's life in light of spiritual goals. For example, a pilgrim seeking deeper meaning retreats from the world to engage new experiences and inhabit a new identity. A child moving into adulthood participates in the rituals of Christian confirmation or Jewish bar/bat mitzvah to transition into adult responsibilities within the community. Couples before taking marriage vows enter the liminal state of "being engaged" to reflect on the obligations they will pledge to a partner and the communities supporting this partnership. Just as pilgrims seeking a time of reflection literally disconnect from familiar locations and everyday responsibilities, those who make formal Buddhist or Christiaan religious retreats withdraw into periods of contemplation with the support of their religious communities. Each of these rituals signifies some level of transformation facilitated by the experiences of the liminal state.

For Tashi entering the forest and Dondup taking to the road, their journeys are retreats from ordinary life into liminality. And while neither character in the film makes his decision as part of an explicitly religious process, the structure of their journeys mirrors that of religious pilgrimage. The liminal state each man enters leads him to reflect on how his actions relate to larger goals. From a Buddhist perspective, the spiritual path permeates everyday life. Thus the events portrayed in the film are part of the process of gaining spiritual knowledge-for the characters as well as for the actors and audience. Dzongsar Jamyang Khyentse, Vajrayana teacher and director of Travelers and Magicians, describes the goal of following a Buddhist spiritual path.

"The aim of following [a] spiritual path is to actualize the truth. Unless we understand the truth, we are constantly deceived by believing that everything illusory is real. This belief is what we call delusion. Having delusion creates emotion, and emotion breeds endless karma and its consequences. This cycle is what we call samsara." (Khyentse 2016, p. 180). Within Travelers and Magicians, Tashi and Dondup are ordinary people moving toward truth, recognizing their delusions. And their transformations resonate with an audience recognizing their own karmic webs.

In the course of the film, the audience drops into liminal time and space as traveler and film viewer: abandoning the familiar, seeking direction, and relinquishing control to the journey itself. The film, like a structured religious ritual promising transformation, controls the movement and marks a path into inside-out worlds. Beckoned by images, the viewer-traveler trusts the ritual to bring a kind 
of purification and renewal. And it does. As the film concludes, boundaries between the narratives and the viewer converge. At the beginning of the film, Dondup and Tashi, full of hope for better lives, head for futures framed by their dreams. But as each man plunges into suffering, he finds he cannot control the world outside himself. Dondup's bus never arrives and Tashi's lover is ultimately beyond reach. As the young men move through their internal and external conflicts, the audience vibrates with its own life experiences.

As the stories in the film unfold and we see each man's sense of an absolute self beginning to unravel, we are reminded of the Buddhist perspective that sees no permanent, constant self, and no unchanging reality. We begin to see filmmaker Khyentse Norbu's characters through the Buddhist lens of dependent arising [pratītyasamutpāda], impermanence, and no self. Although we empathize with Dondup and Tashi, we also see their thoughts/feelings/ideas/decisions as an ever-changing fluidity of causes and conditions. Dondup may return to the village or board a plane for America, but not as the person he was when he began his journey. Tashi may return to his father's farm, but no longer as the day-dreaming schoolboy. Transformed by what the magic allowed him to experience, Tashi has been reshaped by desire, jealousy, anger, grief. And awash in sadness and guilt, his transformation continues.

As viewers, we have been jolted back to the open field where the donkey appears again as a donkey, not a horse, and we grasp that only moments have passed. Having entered our own liminal states of suspended time and responsibilities, immersed as we have been in the desires and fears of Tashi and Dondup, we, too, have changed. We are no longer the same as when we first sat down to view the film.

Of course, the same could be said of any audience viewing a film. But in terms of Buddhist teaching, film-viewing is particularly suited for seeing the process of dependent arising (pratītyasamutpāda). Every image on the screen is quite literally dependent on a myriad of causes and conditions, ranging from the actions of the actors and producers and directors, to the technical decisions of the set-builders and cameramen, to the machines that facilitate unique lighting and editing. Even the eyes and ears and brains of viewers processing images and sounds into coherence are part of this dependently arising experience. Filmmaking, using techniques to quite literally manipulate illusions, is perhaps the most effective way to deconstruct our world of causes and conditions.

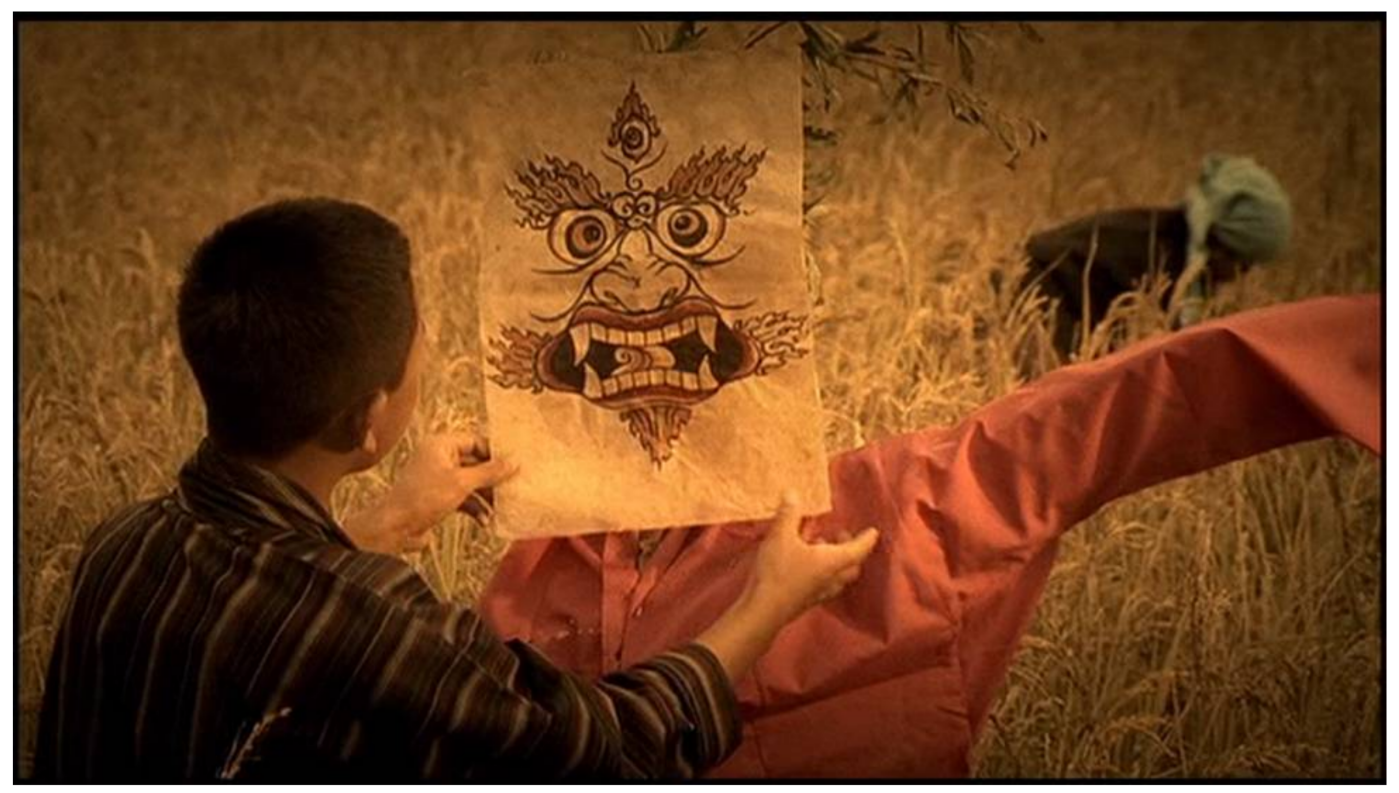

Tashi's younger brother making a scarecrow [from Travelers and Magicians].

In a documentary, Life as Cinema, directed by Anika Tokarchuk, that focuses on director Khyentse Norbu's approach to filmmaking, Khyentse Norbu explains the Buddhist concept of dependent arising [pratìtyasamutpāda] using the experience of cinema as a way to illustrate this teaching. 
Illusion is what we see as something fake, something not permanent, something not solid, something that is not true. [But] in reality, it's the opposite ... from the Buddhist perspective, everything is fake, everything is illusion, everything is dependent. There is not a single thing that is independent, not a single thing that is permanent. That is the reality.

This whole life is like that: a movie, a film, cinema. There are actors, producer, drama, all the romance ... everything fits inside. The thing is: you are the director, you are the producer, and you are also the audience. What we have to do is try to be a good audience and have a better seat, so to speak, so that we see all actions. (Life as Cinema)

In other words, the act of viewing a film offers a unique opportunity to reflect on how we ordinarily see life. Although we experience life as being quite substantive, from a Buddhist perspective, it is more accurately understood as the interplay and interdependence of a myriad of causes and conditions that simply create the illusion of substance.

Discussing his film work, director Khyentse Norbu considers that his filmmaking may be similar to Tibetan thangka painting in that his films explore Buddhist ways of seeing and offer audiences new perspectives to contemplate. As a highly respected Buddhist monk and teacher, formally known as Dzongsar Jamyang Khyentse Rinpoche, he has deep training in the traditions of several Himalayan Buddhist lineages. So given his training as both a Vajrayana teacher and filmmaker, Khyentse Rinpoche is in a unique position to combine them in his art.

Filmmaking is painting with the light and this is my painting. One could always use this medium as the modern-day thangka, modern-day statue. I'm not claiming that all the films that I'm making are something very spiritual. I do not want to proclaim that. Although as a Buddhist, as someone who is trained very rigidly as a Buddhist, there is always some kind of Buddhist influence. (Khyentse Norbu, in the special feature film accompanying Travelers and Magicians: "A Story from Bhutan, the Making of Travelers \& Magicians" directed by Eric Blair.)

In Travelers and Magicians, Khyentse Norbu invites us into Tashi's mind-created world that is, at its core, empty of anything solid to hold on to. He presents it as a dream reality permeated with powerful emotions that seep into his waking reality. The dream metaphor that the film portrays with such immediacy allows us to experience the essentially impermanent and illusory nature of the world that emerges out of Tashi's hopes, and leads us to reflect on the worlds produced by our own minds. The audience directly experiences the Buddhist teaching that all existence is illusion, the product of dependent arising [pratityasamutpāda]. The film invites us to experience the emptiness of existence. In Khyentse Rinpoche's words:

The essence of all of the Buddha's teachings is emptiness, or interdependent arising. Nothing arises, dwells, or ceases independently. Therefore, there's nothing permanent. There is no truly existing self. Everything that we think exists, or does not exist, or both or neither-all these things are fabrications of our mind. We fabricate them and then we become attached to our fabrications. But we don't realize they are our own fabrications. (Dzongsar Jamyang Khyentse Rinpoche; (Khyentse 2017))

Even as Tashi wakes haunted with guilt, fear, and grief, his mind remains in his dream reality. Although now back in the field with his younger brother, he is burdened by what he did only moments ago in the mysterious forest. As viewers, we see the power of Tashi's delusions, and the power of our own. Perhaps the worlds that our minds create are, like Tashi's, the product of causes and conditions, impermanent, with no fixed self. Like the monk pushing Dondup to question whether the grass is really so green in America, the film pushes us to question the realities we hold so firmly.

From a Buddhist perspective, Khyentse Rinpoche explains that our experience of life is very much like entering a powerful drama in a cinema. We identify and empathize deeply with the characters, adopt new positions about rights and wrongs, slip in and out of emotions, and see in new ways. For the 
duration of the performance, our everyday lives recede as our consciousness merges into the world of the film. Even our bodies respond with tears and laughter, white knuckles and edge-of-the-seat numbness. But when we look through the lens of dependent arising, we realize we have confused the dramas. In labelling the "film life" as illusion and "real life" as reality, we have reversed illusion and reality.

Khyentse Norbu suggests that the cinema can be a kind of antidote for deluded thinking. Once open to the possibility that our minds are creating the all-absorbing worlds to which we are so attached, the experience of cinema can be a way to sharpen and deepen our understanding of this perspective. In Khyentse Rinpoche's words:

Let's say, you are born in the cinema, while the film is going on. You never leave the cinema. The only reference in your life is that cinema. We enter into the cinema hall, we sit there, the lights go dim, and the cinema appears. (Life as Cinema)

However, only by stepping outside the cinema can we see the complex illusion of existence: an interdependently arising system of causes and conditions, empty of permanence.

In Travelers and Magicians, Dondup begins to question the absolute certainty of his view that happiness lies only in America. With new causes and conditions to contend with in the form of his fellow travelers, particularly the papermaker's bright, beautiful daughter and the story-telling monk, Dondup's sureness begins to waver. In a visually powerful scene in which the travelers have gathered around a campfire and doubts have begun to surface for Dondup, the camera pulls back for us to see, on the cave wall behind them, the huge painted face of the Buddhist teacher, Padmasambhava or Guru Rinpoche.

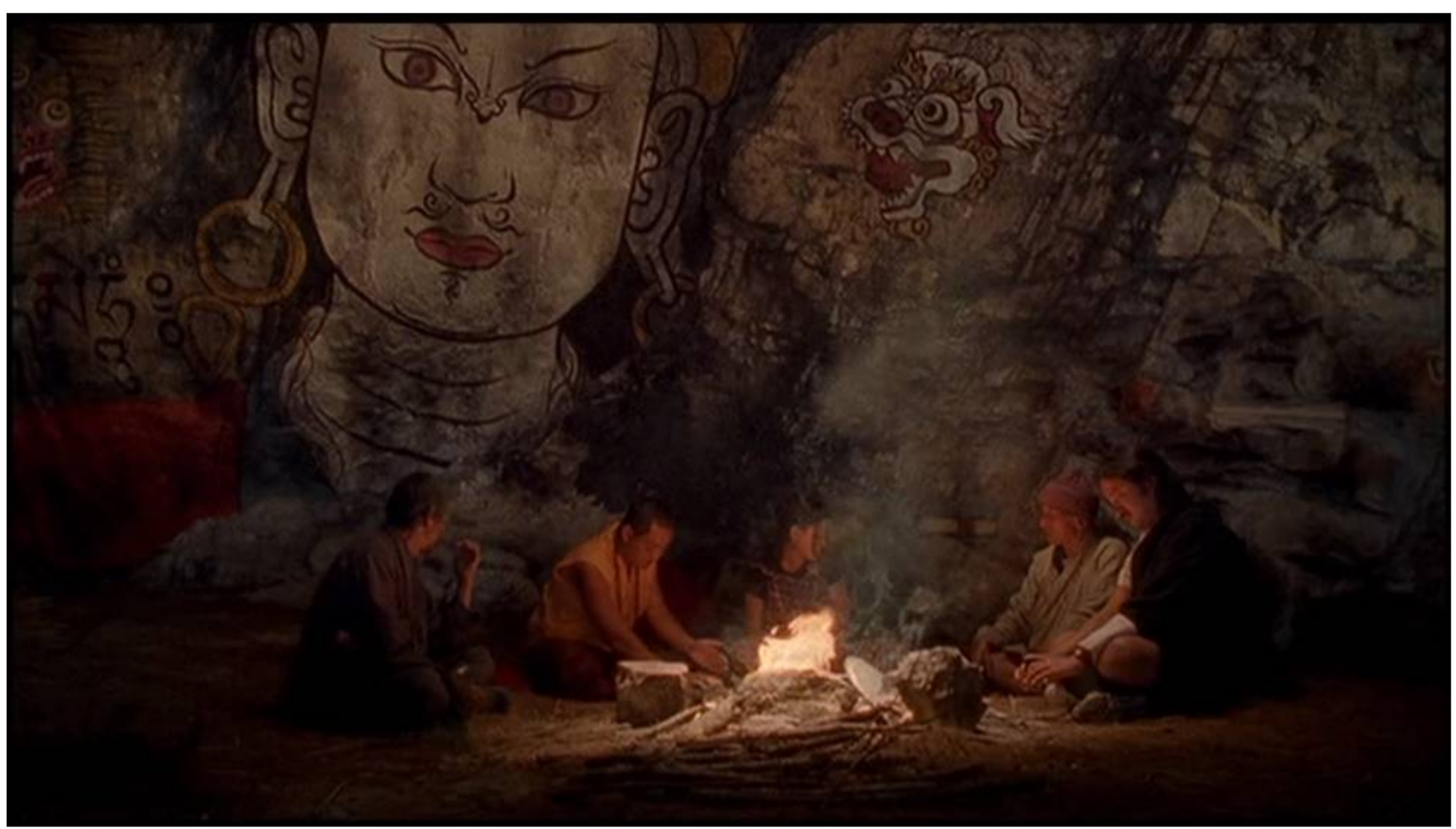

Guru Rinpoche painting on the cave wall behind the five travelers in the film [from Travelers and Magicians].

In Bhutan, Guru Rinpoche is greatly revered for having brought Buddhism to Tibet and Bhutan, and founding the oldest of the Himalayan Buddhist schools, the Nyingma. Dzongsar Jamyang Khyentse's grandfather, the highly respected second Dudjom Rinpoche, was head of the Nyingma school, and Jamyang Khyentse himself was educated by important Nyingmapa teachers including the well-known and honored Dilgo Khyentse Rinpoche.

Placing Dondup and the other characters under the oversized face and eyes of Guru Rinpoche lets the viewer know that his Buddhist teachings and perspectives envelop their thinking and 
interactions. Responding to this image, consciously or subliminally, the viewer also contemplates the foundational Buddhist teachings brought to Bhutan by Guru Rinpoche-impermanence, dependent arising, emptiness-permeating the small perspectives of the five people sitting under his wide awake eyes.

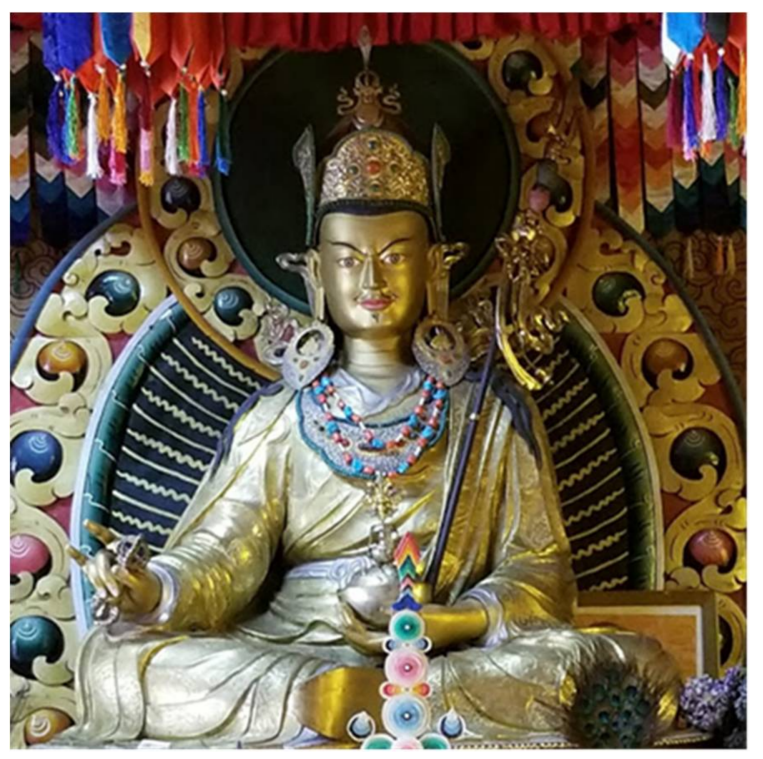

Guru Rinpoche image at Memorial Chorten, Thimphu, Bhutan (photo by Catherine Benton).

Travelers and Magicians directly targets the human predilection for holding on to a substantive view of the world that mistakes illusion for reality. Encouraging us to experience the ephemeral nature of our mind-created worlds, Director Khyentse Norbu invites us to see an alternate view through the Buddhist lens of dependent arising and emptiness.

Conflicts of Interest: I have no association with anyone connected to the production of the film Travelers and Magicians.

\section{References}

Khyentse, Dzongsar Jamyang. 2016. The Guru Drinks Bourbon. Boulder: Shambhala South Asia.

Khyentse, Dzongsar Jamyang Rinpoche. 2017. The Clarity Aspect. Lion's Roar. June 17. Available online: https:/ / www.lionsroar.com/the-clarity-aspect/ (accessed on 28 February 2018).

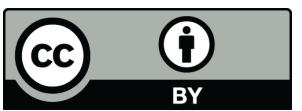

(C) 2018 by the author. Licensee MDPI, Basel, Switzerland. This article is an open access article distributed under the terms and conditions of the Creative Commons Attribution (CC BY) license (http://creativecommons.org/licenses/by/4.0/). 